\title{
Superstructures with cyclodextrins: Chemistry and applications II
}

\author{
Gerhard Wenz
}

\section{Editorial}

\section{Address:}

Saarland University, Organic Macromolecular Chemistry,

Campus C4 2, 66123 Saarbrücken, Germany

Email:

Gerhard Wenz - g.wenz@mx.uni-saarland.de

Keywords:

cyclodextrins
Beilstein J. Org. Chem. 2015, 11, 271-272.

doi:10.3762/bjoc. 11.30

Received: 03 February 2015

Accepted: 04 February 2015

Published: 18 February 2015

This article is part of the Thematic Series "Superstructures with cyclodextrins: Chemistry and applications II".

Guest Editor: G. Wenz

(C) 2015 Wenz; licensee Beilstein-Institut.

License and terms: see end of document.
Cyclodextrins (CDs) are cyclic $\alpha(1 \rightarrow 4)$-linked oligomeres of anhydroglucose. Since the 6-, 7- and 8-membered rings, called $\alpha-, \beta$ - and $\gamma-\mathrm{CD}$, respectively, can be produced through the enzymatic degradation of starch on an industrial scale with high purity [1], CDs are now considered to be the most interesting class of organic host molecules. Furthermore, $\alpha$ - and $\gamma$-CDs are known to be nontoxic and are approved as food additives [2,3]. Since CDs are soluble in water and able to solubilize hydrophobic active ingredients, they are broadly used in biomedical applications [4]. CDs are also well known to complex suitable monomeric and polymeric guest molecules, leading to supramolecular structures and topological compounds, such as rotaxanes and polyrotaxanes [5-7]. The solubility and stability of CD complexes are controllable through the derivatization of CDs. Remarkable progress has been achieved over the past 10 years regarding the regioselective derivatization of cyclodextrins. Synthetic procedures for CD key derivatives such as mono-6- $O$-tosyl- $\beta-\mathrm{CD}$ were optimized to allow for production on a large scale [8]. More than one and up to 6 different substituents have been attached at various defined locations on the $\mathrm{CD}$ ring $[9,10]$. Some $\mathrm{CD}$ derivatives have already found very interesting applications in the design of aqueous-phase catalysts [11]. Many other applications are certain to follow.

The $17^{\text {th }}$ International Cyclodextrin Symposium, held in May 2014 in Saarbrücken, Germany provided an overview of the various aspects of CD chemistry, such as organic synthesis, analysis of inclusion compounds, polymeric and colloidal systems, as well as smart materials and drug delivery. These contributions to Cyclodextrin Chemistry are collected in this Thematic Series of the Beilstein Journal of Organic Chemistry.

Gerhard Wenz

Saarbrücken, January 2015

\section{References}

1. Schallmey, M.; Singh, A.; Ward, O. P. Can. J. Microbiol. 2004, 50, 1-17. doi:10.1139/w03-076 
2. 2008/413/EC: Commission Decision of 26 May 2008 authorising the placing on the market of alpha-cyclodextrin as a novel food ingredient under Regulation (EC) No 258/97 of the European Parliament and of the Council (notified under document number C(2008) 1954; Official Journal of the European Union, 2008. 51,12 (http://eur-lex.europa.eu/legal-content/EN/TXT/?uri=uriserv:OJ.L_.2008 146.01.0012.01.ENG).

3. 2012/288/EU: Commission Implementing Decision of 1 June 2012 authorising the placing on the market of Gamma-Cyclodextrin as a novel food ingredient under Regulation (EC) No 258/97 of the European Parliament and of the Council (notified under document C(2012) 3496; Official Journal of the European Union, 2012, 55, 41. (http://eur-lex.europa.eu/legal-content/EN/TXT/?uri=uriserv:OJ.L_.2012 144.01.0041.01.ENG).

4. Brewster, M. E.; Loftsson, T. Adv. Drug Delivery Rev. 2007, 59 , 645-666. doi:10.1016/j.addr.2007.05.012

5. Wenz, G. Angew. Chem., Int. Ed. Engl. 1994, 33, 803-822. doi:10.1002/anie.199408031

6. Wang, W.; Kaifer, A. E. Cucurbituril and Cyclodextrin Complexes of Dendrimers. In Inclusion Polymers; Wenz, G., Ed.; Advances in Polymer Science, Vol. 222; Springer-Verlag: Berlin, 2009; pp 1-54. doi:10.1007/12_2008_1

7. Harada, A.; Hashidzume, A.; Yamaguchi, H.; Takashima, Y. Chem. Rev. 2009, 109, 5974-6023. doi:10.1021/cr9000622

8. Popr, M.; Hybelbauerová, S.; Jindřich, J. Beilstein J. Org. Chem. 2014, 10, 1390-1396. doi:10.3762/bjoc.10.142

9. Guieu, S.; Sollogoub, M. Advances in Cyclodextrin Chemistry. In Modern Synthetic Methods in Carbohydrate Chemistry; Werz, D. B.; Vidal, S., Eds.; Wiley-VCH: Weinheim, Germany, 2014; pp 241-283. doi:10.1002/9783527658947.ch9

10. Wang, B.; Zaborova, E.; Guieu, S.; Petrillo, M.; Guitet, M.; Blériot, Y.; Ménand, M.; Zhang, Y.; Sollogoub, M. Nat. Commun. 2014, 5, No. 5354. doi:10.1038/ncomms6354

11. Hapiot, F.; Ponchel, A.; Tilloy, S.; Monflier, E. C. R. Chim. 2011, 14, 149-166. doi:10.1016/j.crci.2010.04.003

\section{License and Terms}

This is an Open Access article under the terms of the Creative Commons Attribution License (http://creativecommons.org/licenses/by/2.0), which permits unrestricted use, distribution, and reproduction in any medium, provided the original work is properly cited.

The license is subject to the Beilstein Journal of Organic Chemistry terms and conditions:

(http://www.beilstein-journals.org/bjoc)

The definitive version of this article is the electronic one which can be found at: doi:10.3762/bjoc. 11.30 